\title{
Optimization of Protocols for In Vitro Regeneration of Sugarcane (Saccharum officinarum)
}

\author{
Shakra Jamil, ${ }^{1}$ Rahil Shahzad, ${ }^{1}$ Ghulam Mohyuddin Talha, ${ }^{2}$ Ghazala Sakhawat, \\ Sajid-ur-Rahman, ${ }^{1}$ Razia Sultana, ${ }^{2}$ and Muhammad Zaffar Iqbal ${ }^{1}$ \\ ${ }^{1}$ Agricultural Biotechnology Research Institute, AARI, Faisalabad, Pakistan \\ ${ }^{2}$ Department of Plant Breeding and Genetics, University of Agriculture, Faisalabad, Pakistan \\ Correspondence should be addressed to Rahil Shahzad; rahilshahzad91@gmail.com
}

Received 11 April 2017; Revised 26 June 2017; Accepted 6 August 2017; Published 28 December 2017

Academic Editor: Siva P. Kumpatla

Copyright (C) 2017 Shakra Jamil et al. This is an open access article distributed under the Creative Commons Attribution License, which permits unrestricted use, distribution, and reproduction in any medium, provided the original work is properly cited.

Sugarcane contributes $60-70 \%$ of annual sugar production in the world. Somaclonal variation has potential to enhance genetic variation present within a species. Present study was done to optimize an in vitro propagation protocol for sugarcane. The experiments included four varieties, 9 callus induction media, 27 regeneration media, and 9 root induction media under twofactor factorial CRD. Data were recorded on callus induction, embryogenic callus formation, shoot elongation ( $\mathrm{cm})$, root induction, and plant regeneration. Statistically significant differences existed between genotypes and treatments for callus induction (\%), embryogenic callus formation (\%), shoot elongation $(\mathrm{cm})$, root induction, and plant regeneration (\%). All parameters showed dependency on genotypes, culture media, and their interaction. Highest callus induction (95\%) embryogenic callus formation (95\%) was observed in callus induction media 5. Highest plantlet regeneration (98.9\%) capacity was observed in regeneration media 11 whereas maximum shoot elongation $(12.13 \mathrm{~cm})$ and root induction $(8.32)$ were observed in rooting media $4 . G_{1}$ showed best response for all traits and vice versa for $G_{4}$. Hence it was concluded that $G_{1}$, callus induction media 5 , regeneration media 11 , and rooting media 4 are the best conditions for in vitro propagation of sugarcane.

\section{Introduction}

Sugarcane is a strong and tall crop. It belongs to perennial grasses. It has high sugar content. Commonly grown sugarcane cultivar is Saccharum officinarum which belongs to family Poaceae. It is an important industrial crop in tropical and subtropical regions of the world. Properties such as an efficient photosynthetic machinery and efficient biomass production make it an excellent target for industrial processing and a valuable alternative for animal feeding and the production of byproducts. It is also a prime candidate as a fuel crop (production of ethanol). Byproducts from sugarcane include molasses, stock feed, alcoholic drinks, bagasse, and cane wax [1].

Sugarcane provides major raw material for sugar producing industries [2]. It ranks among the world's top ten food crops and contributes $60-70 \%$ of annual sugar production in the world. Nowadays it has appeared as an important bioenergy field crop [3]. Pakistan ranks 5th in sugarcane producing countries with respect to area under cultivation and holds 15th position with respect to sugar production [4]. Sugarcane crop contributes 3.2 percent as value addition in agriculture and $0.7 \%$ in GDP [5].

With the uses of conventional, modern breeding, and advanced biotechnological approaches, sugarcane is becoming model crop for the future. It also promises to fulfill food, fiber, feed, and biofuel requirements of quickly growing world population. To meet the increasing sugar demand and to make sugarcane a beneficial crop to farmers it is required to advance the quality and quantity of sugarcane and sugar production per unit area $[6,7]$. The other major challenges to be addressed by the sugarcane breeders include biotic stresses (pests, diseases, and weed competition), abiotic stresses (drought, salinity, cold, aluminum toxicity, and compact soils), and plant architecture including stalk number, height, leaf angle, and plant vigor [8-11]. 
In vitro propagation and other in vitro techniques are in common use in agriculture and horticulture for solving various problems related to plant and mass propagation of crop plants [12]. In vitro propagation of sugarcane is a model system to investigate sugar uptake [13], sugar metabolism [14], disease control [15], improvement of yield components [16], and weed control via herbicide tolerance [17]. Use of plant tissue culture is a preferable technique to solve the agricultural problems over conventional methods, as plants are grown in controlled environment in tissue culture.

It has been observed that, in many plant regeneration systems, callus induction is initiated by 2, 4-D at different concentrations [18]. Also the success of the sugarcane tissue culture is also dependent on sugarcane genotypes [19], culturing medium and use of growth enhancer \& regulators [20]. Therefore the present study was designed with four sugarcane cultivars developed by Sugarcane Research Institute, AARI, Faisalabad, to check the effect of cultivar, different media compositions on the callus induction, embryogenic callus formation, and plant regeneration. In addition, we have also carried out optimization of protocol for in vitro propagation of sugarcane.

\section{Material and Methods}

The present research work was done in the Genetically Modified Organism Testing Laboratory, Agricultural Biotechnology Research Institute, AARI Faisalabad, during 2016.

2.1. Media Preparation for Callus Induction, Callus Regeneration, and Plantlet Regeneration. Different types of callus induction and regeneration media with different concentrations of 2, 4-D, BAP, and NAA were prepared (Table 1). The $\mathrm{pH}$ of the media was adjusted to 5.8 with $0.1 \mathrm{~N} \mathrm{NaOH}$ and $0.1 \mathrm{~N} \mathrm{HCl}$. Phytagel at $2.5 \mathrm{~g} / \mathrm{L}$ was added to solidify the media. Media were then autoclaved for $20 \mathrm{~min}$ at $121^{\circ} \mathrm{C}$.

2.2. Explant Selection, Preparation, and Culturing for Callus Induction. The four sugarcane (Saccharum sp.) varieties, namely, CPF-246 $\left(G_{1}\right), \mathrm{CPF}-247\left(G_{2}\right), \mathrm{CPF}-248\left(G_{3}\right)$, and CPF-249 $\left(G_{4}\right)$, were obtained from the Sugarcane Research Institute, Ayub Agricultural Research Institute, Faisalabad. Stalk pieces were sown in pots containing soil in greenhouse. Pots were irrigated every two days with tap water. Sugarcane plants were kept in the same conditions approximately for six months. The plant material used for callus inductions was innermost layer of the leaves. The explants were surface sterilized for $10 \mathrm{~min}$ in ten percent bleach, followed by three rinses with sterile distilled water. Then plant part was put on sterile filter paper for drying purpose. Innermost layer of the leaf was obtained and was cut into $5 \mathrm{~mm}$ pieces which were separately placed on aseptic media. Two explants per test tubes were cultivated and cultures were kept in the dark at $25 \pm$ $1^{\circ} \mathrm{C}$. Callus induction percentage was determined after four weeks. Media were refreshed in each callus after every second week.

2.3. Identification of Embryonic and Nonembryogenic Callus. Difference between nonembryogenic and embryogenic callus was achieved on the basis of callus physical characteristic $[21,22]$. Embryogenic callus is of smooth trait, compact, and described by its white-cream colour and its nodularlike arrangement. But nonembryogenic callus is of wet trait, translucent, or of brownish colour. After four weeks of culture, the number of embryogenic calli was noted for all treatment combinations.

2.4. Plantlet Regeneration, Shoot Elongation, Root Formation, and Acclimatization of the Regenerated Plants. Embryogenic calli were transferred in Petri dishes containing regeneration media (MS modified). Different types (27) of media prepared with different combinations of sucrose, BAP, and NAA keeping the MS salt in constant amount (e.g., $4.6 \mathrm{~g} / \mathrm{L}$ ) were used for plantlet regeneration. Cultures were placed in growth room at $25 \pm 1^{\circ} \mathrm{C}$ under $16 \mathrm{~h}$ light (1000 lux). Regeneration of plants from each of the calli was recorded consecutively for 4 weeks. Data were recorded on number of regenerated shoots for four weeks and media were changed after every second week. Regenerated plantlets were then shifted on different combinations of (NAA) root induction media (Table 1). Shoot elongation and rooting induction were recorded for four weeks. Plants with well-developed roots were transferred to disposable cups filled with soil, under high humidity (>90\%), by covering the plants with plastic wraps after cutting their leaves [23]. Plants were kept in green house at $25 \pm 1^{\circ} \mathrm{C}$ under $16 \mathrm{~h}$ light for hardening. Later on plants were shifted to field. Plants were said to be acclimatized when new leaves and roots were formed in the field conditions.

2.5. Statistical Analysis. Data regarding number of induced callus, the number of embryogenic callus, plantlet regeneration, shoot elongation, and root induction were subjected to analysis of variance according to Steel et al. [24].

\section{Result and Discussion}

An efficient system for in vitro propagation of sugarcane has been optimized and results obtained in the above experiments are summarized here.

3.1. Callus Induction. For callus induction 9 different media formulations with varying concentrations of the sucrose and 2, 4-D (Table 1) along with four genotypes CPF-246, CPF-247, CPF-248, and CPF-249 were used. Genotypes, media, and their interaction significantly differed for callus induction $(p<0.05)$ Table 2 . The results indicated that the callus induction varied from $40 \%$ to $95 \%$ (Figure 1). These high callus induction percentages explained the high capacity of the tested sugarcane genotypes to induce callus. Genotype 1 and 3 have the highest callus induction percentages (95\% and 90\%, resp.) with white creamy callus (Figure 5(a)), while genotype 4 has the lowest callus induction (40\%). Genotype 3 showed an intermediate $(70 \%)$ callus induction. Similar results were also reported by Gandonou et al. [19] who studied the effect of genotypes on callus induction in sugarcane and reported high callus induction (95\%) in Clone III.

Highest callus induction was observed with media 5 (MS salt $4.6 \mathrm{~g} / \mathrm{L}, 2,4-\mathrm{D} 2.0 \mathrm{mg} / \mathrm{L}$, and sucrose $30 \mathrm{~g} / \mathrm{L}$ ) and 


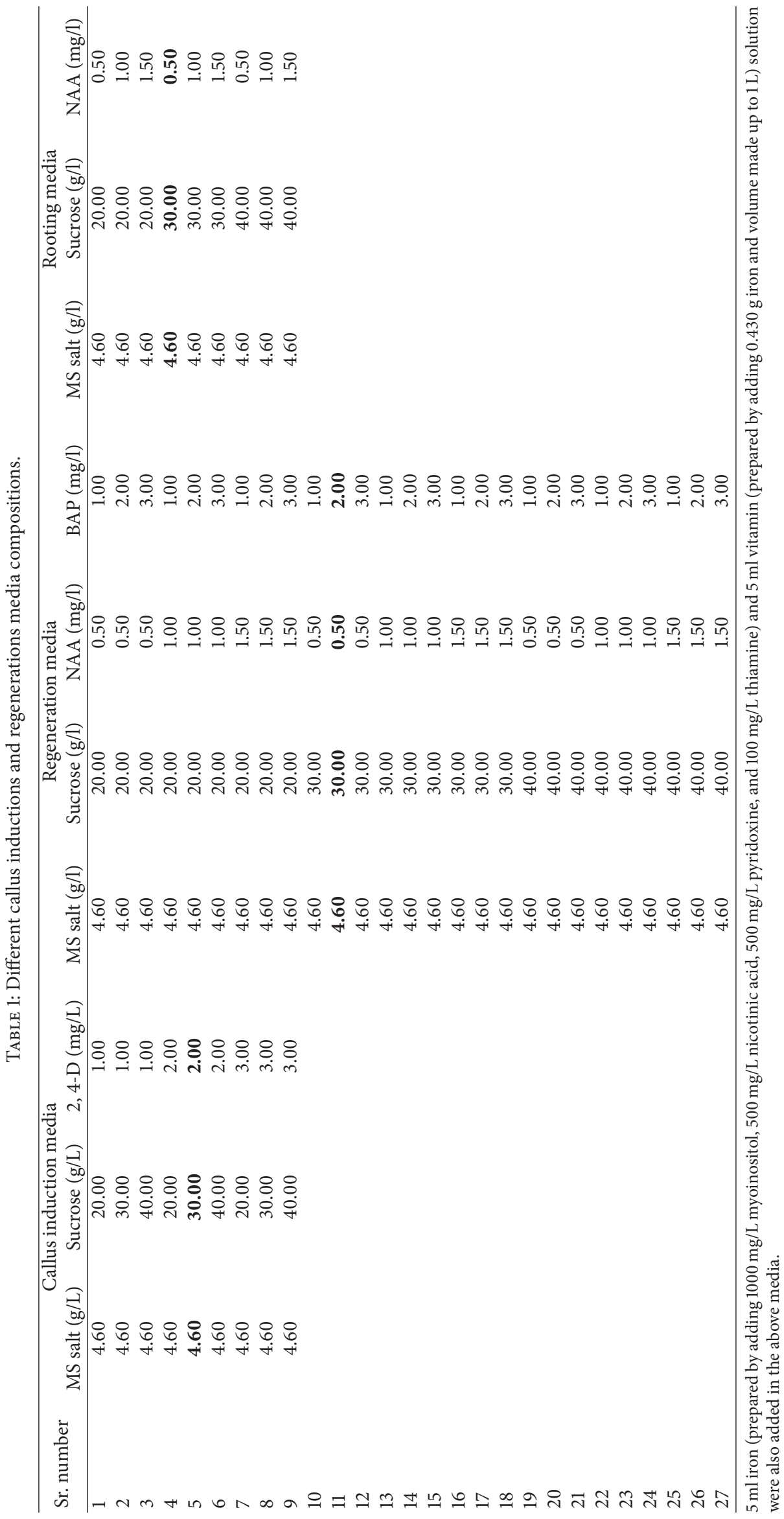




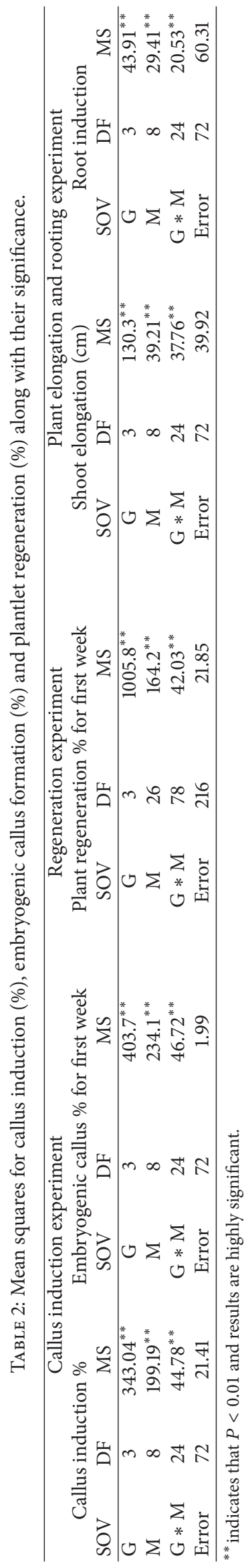




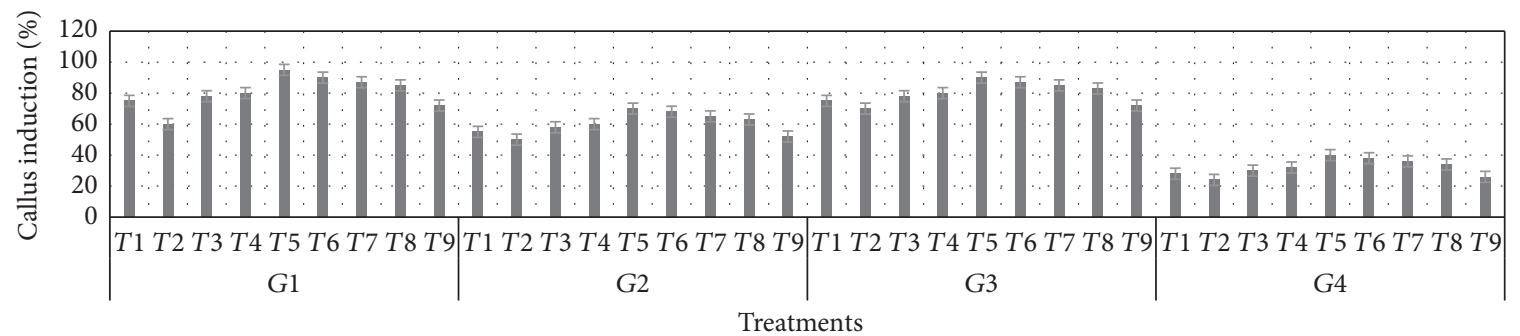

FIGURE 1: Effect of different callus induction media on callus induction (\%) in sugarcane. $G_{1}-G_{4}$ are CPF-246, CPF-247, CPF-248, and CPF249 , respectively, and $T_{1}-T_{9}$ are different media compositions in accordance with callus induction media portion of Table 1 .

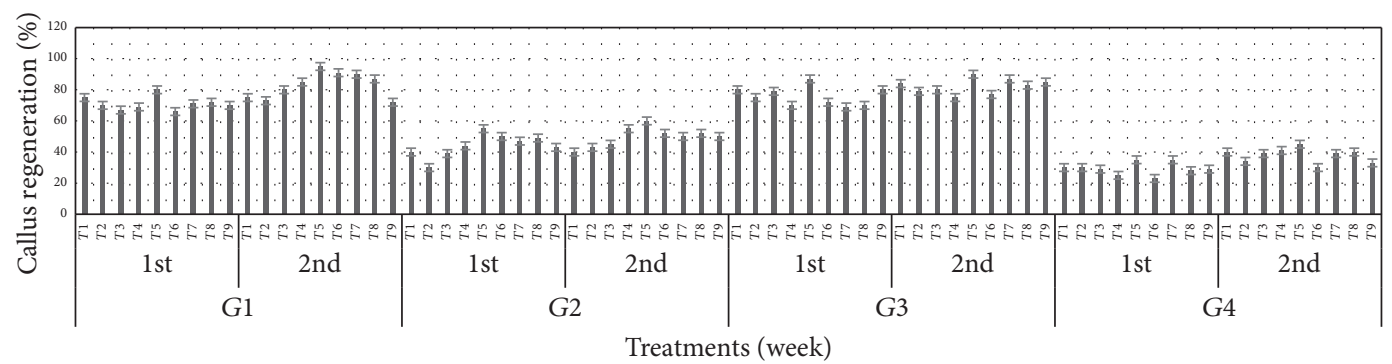

FiguRE 2: Effect of different plantlet regeneration media on embryogenic callus formation (\%) in sugarcane. 1st to 2 nd week indicates the reading for week 1 and week 2 , respectively. $G_{1}-G_{4}$ are CPF-246, CPF-247, CPF-248, and CPF-249, respectively, and $T_{1}-T_{27}$ are different media compositions in the regeneration media portion of Table 1.

lowest callus induction was observed with callus induction media 2 (MS salt $4.6 \mathrm{~g} / \mathrm{L}, 2,4-\mathrm{D} 1 \mathrm{mg} / \mathrm{L}$, and sucrose $30 \mathrm{~g} / \mathrm{L}$ ). These results showed that callus induction ability depends on genotype, culture media, and their interaction. Similar results were also observed by Gandonou et al. [19] and Khan et al. [2]. Begum et al. [25] observed that $3.5 \mathrm{mg} / \mathrm{l}$ of 2, 4-D gave maximum callus induction in Bangladeshi sugarcane variety Nagabari. Islam et al. [26] demonstrated that $0.5-5.0 \mathrm{mg} / \mathrm{l}$ of 2, 4-D gave maximum callus induction from the sugarcane leaf tissues supplemented with MS media.

3.2. Embryogenic Callus. Embryogenic callus shows the ability of the callus to regenerate plant from one cell or few numbers of cells. Difference between embryogenic and nonembryogenic callus was achieved on the basis of callus physical appearance as reported by [19]. In addition to these two previous types, we observed an intermediary type with a nonembryogenic tissue covered by an embryogenic tissue. This type of callus was also observed previously for sugarcane [27] and sorghum [28]. For embryogenic calli percentage determination, we classified the intermediary type as embryogenic because, in further subcultures, the embryogenic tissue grows faster than nonembryogenic tissue.

Embryogenic callus formation was recorded for two weeks and was higher in the second week as compared to week 1 irrespective of the genotypes and treatments. Statistical analysis showed significant differences between genotype, treatments, and their interaction for embryogenic callus formation (Table 2). The highest embryogenic callus was observed in $G_{1}(95 \%)$ followed by $G_{3}(90 \%)$ in 2 nd week. The trend was similar for the genotype in the first week. The lowest embryogenic callus was observed in $G_{4}(23,35 \%)$, respectively, in the first and second week. Maximum embryogenic callus formation was found in media 5 for second week $(95,60,90$, and $45 \%)$ and first week $(80,55,87$, and $35 \%)$, respectively, for $G_{1}$ to $G_{4}$ (Figure 2). Previously similar results were reported by Verma et al. [29] in crocus and Gandonou et al. [19] in sugarcane. Molina et al. [30] also reported that somatic embryogenesis in coffee plant is affected by genotype and month of leaf collection. Somatic embryogenesis varied from 4.8 to $72.4 \%$ across genotypes in their experiment.

3.3. Plant Regeneration. Embryogenic callus was grown on regeneration media. Media 11 showed best results for plantlet regeneration. The number of plantlets regenerated per callus was also very high (Figure 3 ). High regeneration ability was found in $G_{1}$ followed by $G_{3}$ whereas $G_{2}$ and $G_{4}$ showed low regeneration ability. Maximum and minimum regeneration ability were observed in $G_{1}(91.3,93.3,94.3$, and $98.9 \%)$ and $G_{4}(60.9,62.8,65.7$, and $69.9 \%)$, respectively, from 1st week to the 4 th week. Regeneration ability of the remaining two genotypes was in between these two (Figure 3). Cultivars, having high regeneration ability, are useful in tissue culture programs. These results illustrated that plant regeneration capacity is a cultivar dependent trait and it is likely that this trait is being controlled by one or a block of genes (Figure 3 ). These results are in line with the previous results of Birsin and Özgen [31] in Triticosecale who reported that Mikham 2002 and Presto cultivars showed higher regeneration ability than the other genotypes.

Different types of regeneration media with varying concentrations of sucrose, BAP, and NAA were used to optimize media for plantlet regeneration. Best media combination for plant regeneration was media 11 (MS salt $4.6 \mathrm{~g} / \mathrm{L}$, sucrose 


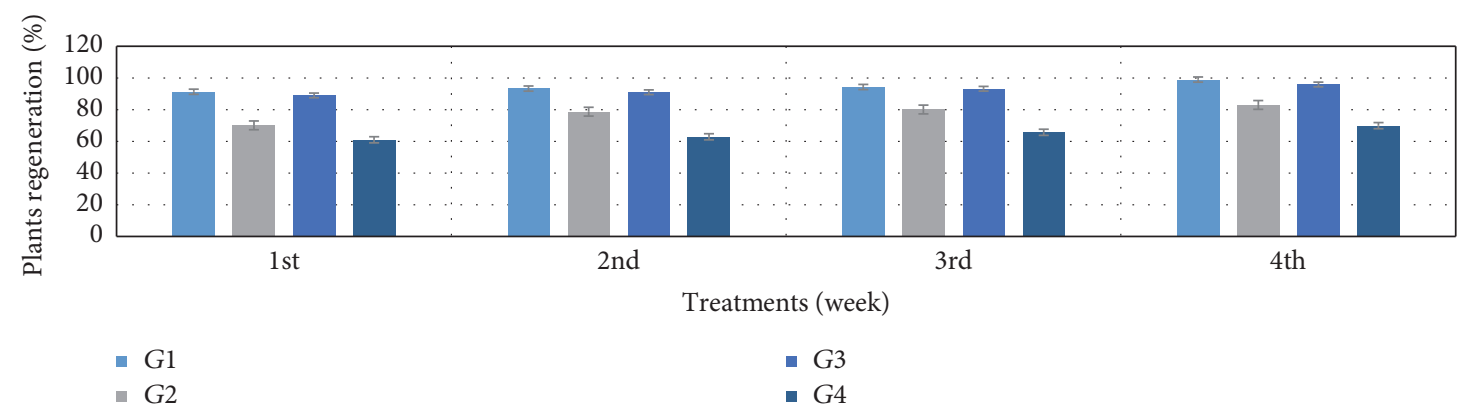

FIGURE 3: Effect of regeneration media 11 on plants regeneration (\%) in sugarcane. 1st to 4 th week indicate the reading for each week whereas $G_{1}-G_{4}$ are CPF-246, CPF-247, CPF-248, and CPF-249, respectively.

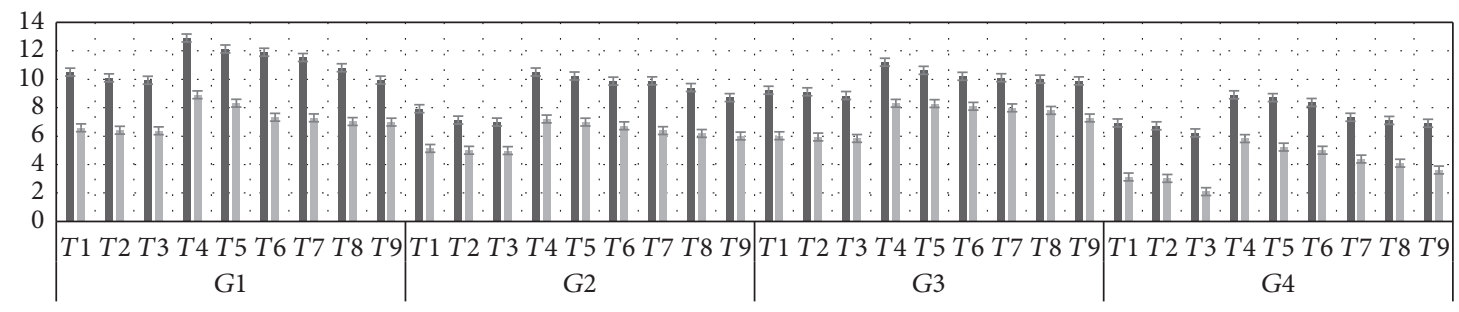

$$
\begin{aligned}
& \text { - Shoot elongation } \\
& \text { - Root induction }
\end{aligned}
$$

FIGURE 4: Effect of different rooting media on shoot elongation and root induction. $G_{1}-G_{4}$ are CPF-246, CPF-247, CPF-248, and CPF-249, respectively, and $T_{1}-T_{9}$ are different media compositions in the rooting media portion of Table 1 .

$30 \mathrm{~g} / \mathrm{L}$, BAP $2.0 \mathrm{mg} / \mathrm{L}$, and NAA $0.50 \mathrm{mg} / \mathrm{L}$ ). Plant regeneration was comparatively low in the rest of the media tested. The results for the best treatment are given in Figure 3 from 1st week to 4 th week and best regenerated plants in Figure 5(b). However the genotypic response for plantlet regeneration was the same as was found for callus induction and embryogenic callus formation; that is, maximum plantlet was observed in $G_{1}$ followed by $G_{3}$ and lowest plantlet was observed in the cultures of $G_{4}$. The results are also in line with the Verma [29] in crocus. They reported that using NAA and BAP together gave better regeneration. However Ather et al. [32] reported that only BAP@ @ $1 \mathrm{mg} / \mathrm{L}$ alone was found optimum and showed maximum shoot emergence from sugarcane callus.

3.4. Shoot Elongation and Root Induction. Auxins (NAA) are involved in several crucial morphogenetic and biochemical responses, that is, promotion of root induction and shoot elongation in plant axial portions (stem and flower pedicels) [33]. Effect of naphthalene acetic acid on shoot elongation and root induction in sugarcane was evaluated in this study. Nine different compositions of rooting media with varying levels of NAA and sucrose keeping MS salt constant $(4.6 \mathrm{~g} / \mathrm{L})$ were used (Table 1). All the treatments showed significant differences for shoot elongation and root induction (Table 2). Highest shoot length $(12.9 \mathrm{~cm}$, Figure 5(c)) and maximum root induction (8.91 roots, Figures $5(\mathrm{~d})-5(\mathrm{f})$ ) were observed with rooting media 4 and $G_{4}$ (Figure 4 ). From these results it was concluded that NAA at $0.5 \mathrm{mg} / \mathrm{L}$ is optimum level for shoot elongation. Lal and Sing [34] also reported that NAA is the ideal growth regulator for induction of rooting in the sugarcane. However Khan et al. [2] reported that instead of NAA, IBA is ideal growth regulator for root induction in sugarcane.

\section{Conclusion}

Our findings showed that callus induction capacity, embryogenic callus response, plantlet regeneration, shoot elongation, and root induction in sugarcane are influenced by genotype and culture media. Growth regulator concentrations used for callus induction also differently affected plant regeneration in the sugarcane varieties. Furthermore, the four genotypes described in this study reacted well to in vitro culture especially to embryogenic callus formation and plantlet regeneration. Maximum callus induction, embryogenic callus formation, plantlet regeneration, shoot elongation, and root induction were observed in $G_{1}$ followed by $G_{3}$. Further, we have also observed that the media compositions were equally important and, out of the media tested in this study, we have identified the best media for callus induction, plantlet regeneration, and shoot elongation and rooting. The study will fill the knowledge gap and will be helpful in deciding the suitable cultivar for micropropagation studies in sugarcane as well as other crops. A complete protocol for the in vitro propagation of sugarcane has been optimized which will also help researchers interested in micropropagation of sugarcane. It is further suggested that the plethora of genes involved in 


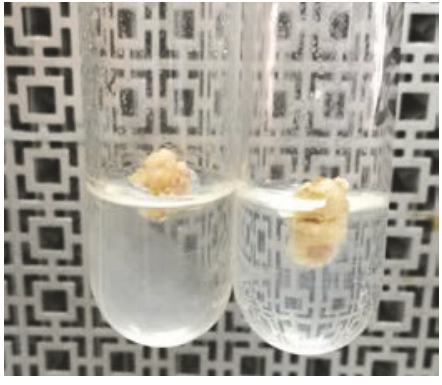

(a)

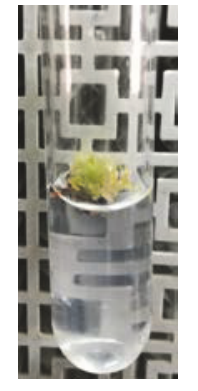

(b)

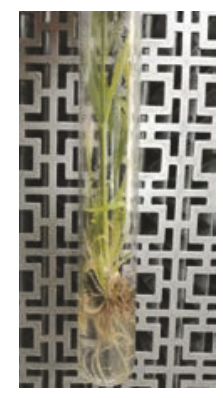

(c)

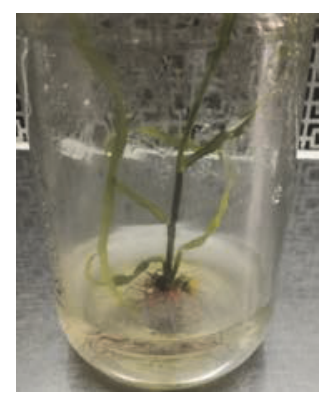

(d)

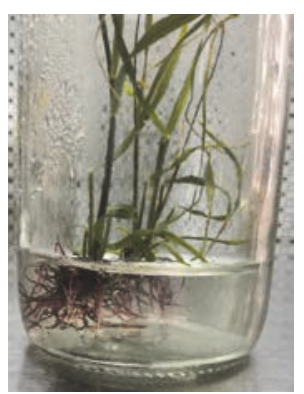

(e)

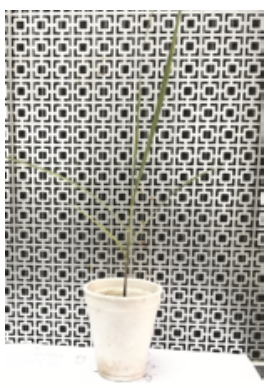

(f)

FiguRE 5: Pictorial presentations of the (a) in vitro callus induction, (b) regenerated callus, (c) regenerated shoots, (d) mature shoot, (e) rooted plants, and (f) potted plant under best treatment of callus induction media (media 5) and regeneration media (media 11).

specific response of cultivar to tissue culture media needs be explored for better understanding of the phenomena.

\section{Conflicts of Interest}

The authors declare that they have no conflicts of interest.

\section{Acknowledgments}

The authors are thankful to Genetically Modified Organisms Testing Lab, Agricultural Biotechnology Research Institute, and Sugarcane Research Institute, AARI Faisalabad, for the funding of this project and providing plant material, respectively.

\section{References}

[1] M. Gallo-Meagher, R. G. English, and A. Abouzid, “Thidiazuron stimulates shoot regeneration of sugarcane embryogenic callus," In Vitro Cellular and Developmental Biology - Plant, vol. 36, no. 1, pp. 37-40, 2000.

[2] I. A. Khan, A. Khatri, M. A. Siddiqui, G. S. Nizamani, and S. Raza, "Performance of promising sugarcane clone for yield and quality traits in different ecological zones of Sindh," Pakistan Journal of Botany, vol. 36, no. 1, pp. 83-92, 2004.

[3] A. J. Waclawovsky, P. M. Sato, C. G. Lembke, P. H. Moore, and G. M. Souza, "Sugarcane for bioenergy production: an assessment of yield and regulation of sucrose content," Plant Biotechnology Journal, vol. 8, no. 3, pp. 263-276, 2010.

[4] A. Bashir, S. Haq, M. Abbas, M. A. Munir, and A. Afzal, "Impact of sugarcane mills development activities on cane production in Punjab," Pakistan J. Agri. Res, vol. 25, pp. 21-27, 2012.
[5] Economic Survey of Pakistan, "Impact of Social Media Applications on Small Business Entrepreneurs," in Management and Economics Research Journal, p. 20, Finance and Economic Affairs Division, Ministry of Finance, Govt. of Pakistan, Islamabad, Pakistan, 2012.

[6] Qureshi, M. Asghar, and S. Afghan, Sugarcane cultivation in, Pakistan. Sugar Book Pub. Pakistan Society of Sugar Technologist, 2005.

[7] M. Y. Arain, R. N. Panhwar, N. Gujar et al., "Evaluation of new candidate sugarcane varieties for some qualitative and quantitative traits under Thatta agro-climatic conditions," Journal of Animal and Plant Sciences, vol. 21, no. 2, pp. 226-230, 2011.

[8] L. C. C. Carvalho, "Evolution of Sugarcane Industry in the State of São Paulo," in Sugar Cane Bioethanol: $R$ and D for productivity and sustainability, L. A. B. Cortez, Ed., vol. 3, Blucher, São Paulo, Brazile, 16 edition, 2010.

[9] S. Creste, L. R. Pinto, M. A. Xavier, and M. G. A. Landell, "Sugarcane Breeding Method and Genetic Mapping," in Sugar Cane Bioethanol: $R$ and D for productivity and sustainability, L. A. B. Cortez, Ed., pp. 353-357, Blucher, São Paulo, Brazile, 2010.

[10] P. H. Moore, F. C. Botha, R. T. Furbank, and C. P. L. Grof, "Potential for Overcoming Physico-biochemical Limits to Sucrose Accumulation," in Proceedings of the Intensive Sugarcane Production: Meeting the Challenges beyond, 2000, CAB International, B. A. Keating and J. R. Wilson, Eds., pp. 141-156, Wallingford, UK, 2000.

[11] A. Khatri, I. A. Khan, M. A. Javed et al., "Studies on callusing and regeneration potential of indigenous and exotic sugarcane clones," Asian Journal of Plant Sciences, vol. 1, no. 1, pp. 41-43, 2002.

[12] H. Schmauder, "E. F. George and P. D. Sherrington, Plant Propagation by Tissue Culture - Handbook and Directory of Commercial Laboratories. VIII + 709 S., 12 Abb., 40 Tab. Eversley, 
Basingstoke 1984. Exegetics Limited. £ 65.00. ISBN: 0-95093250-7," Journal of Basic Microbiology, vol. 25, no. 7, pp. 475-475, 1985.

[13] A. Maretzki and M. Thom, "Membrane transport of sugars in cell suspensions of sugarcane: I. Evidence for sites and specificity," Plant Physiology, vol. 49, no. 2, pp. 177-182, 1972.

[14] R. Wendler, R. Veith, J. Dancer, M. Stitt, and E. Komor, "Sucrose storage in cell suspension cultures of Saccharum sp. (sugarcane) is regulated by a cycle of synthesis and degradation," Planta, vol. 183, no. 1, pp. 31-39, 1991.

[15] Y. Parmessur, S. Aljanabi, S. Saumtally, and A. Dookun-Saumtally, "Sugarcane yellow leaf virus and sugarcane yellows phytoplasma: Elimination by tissue culture," Plant Pathology, vol. 51, no. 5, pp. 561-566, 2002.

[16] J. W. Hoy, K. P. Bischoff, S. B. Milligan, and K. A. Gravois, "Effect of tissue culture explant source on sugarcane yield components," Euphytica, vol. 129, no. 2, pp. 237-240, 2003.

[17] I. A. Nasir, B. Tabassum, Z. Qamar et al., "Herbicide-tolerant sugarcane (Saccharum officinarum L.) plants: An unconventional method of weed removal," Turkish Journal of Biology, vol. 38, no. 4, pp. 439-449, 2014.

[18] G. Zahra Jahangir, I. Ahmad Nasir, R. Ahmad Sial, M. Aslam Javid, and T. Husnain, "Various Hormonal Supplementations Activate Sugarcane Regeneration In-Vitro," Journal of Agricultural Science, vol. 2, no. 4, 2010.

[19] C. Gandonou, T. Errabii, J. Abrini, M. Idaomar, F. Chibi, and N. Skali Senhaji, "Effect of genotype on callus induction and plant regeneration from leaf explants of sugarcane (Saccharum sp.)," African Journal of Biotechnology, vol. 4, no. 11, pp. 1250-1255, 2005.

[20] V. Saharan, R. C. Yadav, N. R. Yadav, and B. P. Chapagain, "High frequency plant regeneration from desiccated calli of indica rice (Oryza Sativa 1.)," African Journal of Biotechnology, vol. 3, no. 5, pp. 256-259, 2004.

[21] M. W. Nabors, J. W. Heyser, T. A. Dykes, and K. J. DeMott, "Long-duration, high-frequency plant regeneration from cereal tissue cultures," Planta, vol. 157, no. 5, pp. 385-391, 1983.

[22] A. Pellegrineschi, R. M. Brito, S. McLean, and D. Hoisington, "Effect of 2,4-dichlorophenoxyacetic acid and $\mathrm{NaCl}$ on the establishment of callus and plant regeneration in durum and bread wheat," Plant Cell, Tissue and Organ Culture, vol. 77, no. 3, pp. 245-250, 2004.

[23] P. Paulet and C. Glaszmann, "Les biotechnologies ensoutien $\alpha$ la diffusion vari@tale chez la canne a sucre," Agriculture et development, vol. 2, p. 1, 1994.

[24] R. G. Steel, J. H. Torrie, and D. A. Dickey, Principles and procedures of statistic: a biometrical approach, 1980.

[25] S. Begum, L. Hakim, and M. A. Azam, "Efficient regeneration of plants from leaf base callus in sugarcane," Plant Tissue Cult, p. 5, 1995.

[26] A. S. Islam, H. A. Begum, and M. M. Haque, "Regeneration of Saccharumofficinarum for disease resistant Varieties," in Proc. Int. Cong. Plant Tissue and Cell Culture, vol. 5, pp. 709-710, 709710, 5, 1982.

[27] E. Guiderdoni, "L’embryogenèse somatique des explants foliaires de canne à sucre (Saccharumsp.) cultivés in vitro," in $L$ Agronomie Tropicale, vol. 41, pp. 50-57, I- Initiation des cultures. L’ Agronomie Tropicale, 1986.

[28] C. MacKinnon, G. Gunderson, and M. W. Nabors, "Plant regeneration by somatic embryogenesis from callus cultures of sweet sorghum," Plant Cell Reports, vol. 5, no. 5, pp. 349-351, 1986.
[29] S. K. Verma, A. K. Das, G. S. Cingoz, E. Uslu, and E. Gurel, "Influence of nutrient media on callus induction, somatic embryogenesis and plant regeneration in selected Turkish crocus species," Biotechnology Reports, vol. 10, pp. 66-74, 2016.

[30] D. M. Molina, M. E. Aponte, H. Cortina, and G. Moreno, "The effect of genotype and explant age on somatic embryogenesis of coffee," Plant Cell, Tissue and Organ Culture, vol. 71, no. 2, pp. 117-123, 2002.

[31] M. A. Birsin and M. Özgen, "A comparison of callus induction and plant regeneration from different embryo explants of triticale (x Triticosecale Wittmack)," Cellular and Molecular Biology Letters, vol. 9, no. 2, pp. 353-361, 2004.

[32] A. Ather, S. Khan, A. Rehman, and M. Nazir, "Optimization of the protocols for callus induction, regeneration and acclimatization of sugarcane CV. Thatta-10," Pakistan Journal of Botany, vol. 41, no. 2, pp. 815-820, 2009.

[33] B. Kaviani, A. A. Hesar, A. Tarang, S. B. Zanjani, D. Hashemabadi, and M. H. Ansari, "Effect of kinetin (Kn) and naphthalene acetic acid (NAA) on the micropropagation of Matthiolaincana using shoot tips, and callus induction and root formation on the leaf explants," Afr. J. Agri. Res, vol. 8, no. 30, pp. 41344139, 2013.

[34] N. Lal and N. H. Sing, "Rapid clonal multiplication of sugarcane through tissue culture," Plant Tissue Cult, vol. 4, pp. 1-7, 1994. 


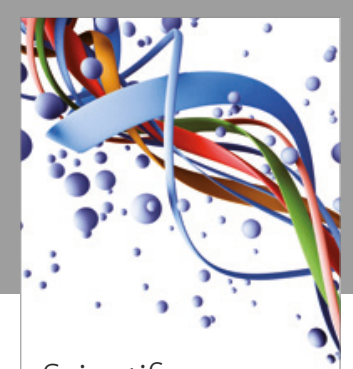

Scientifica
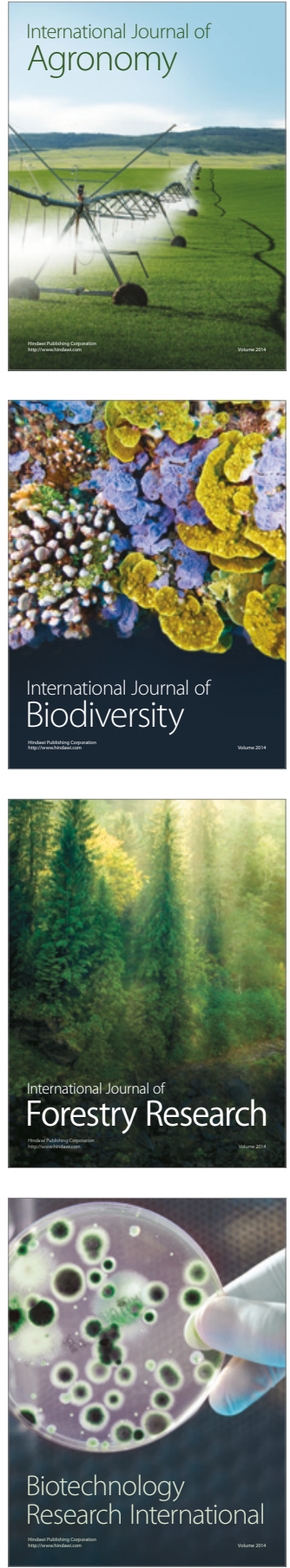
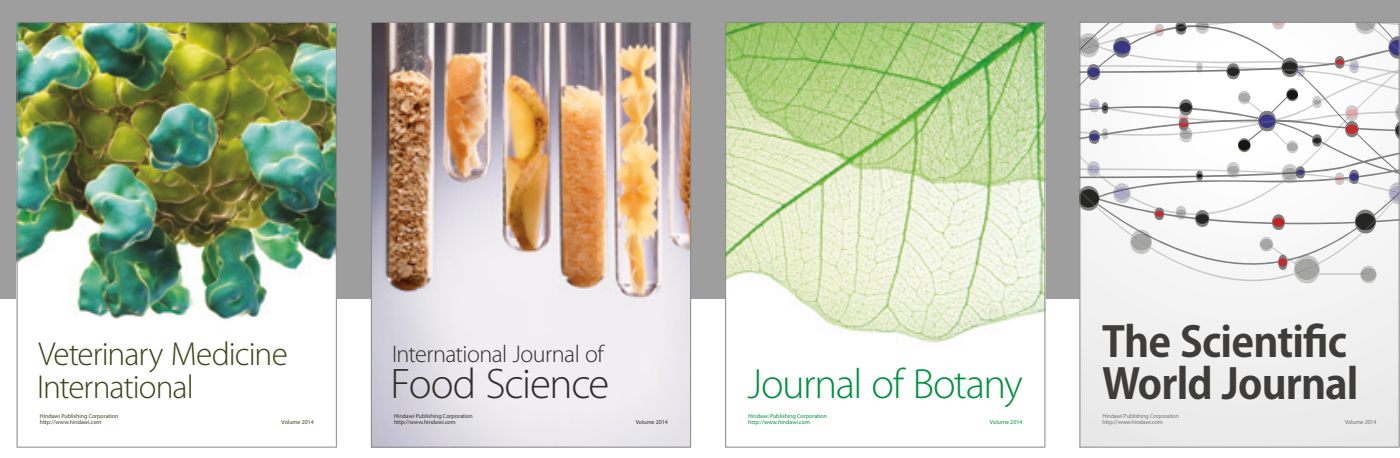

The Scientific

\section{World Journal}

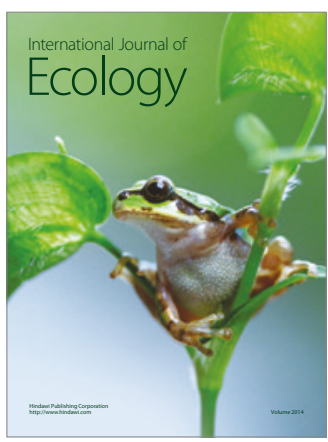

\section{Hindawi}

Submit your manuscripts at

https://www.hindawi.com
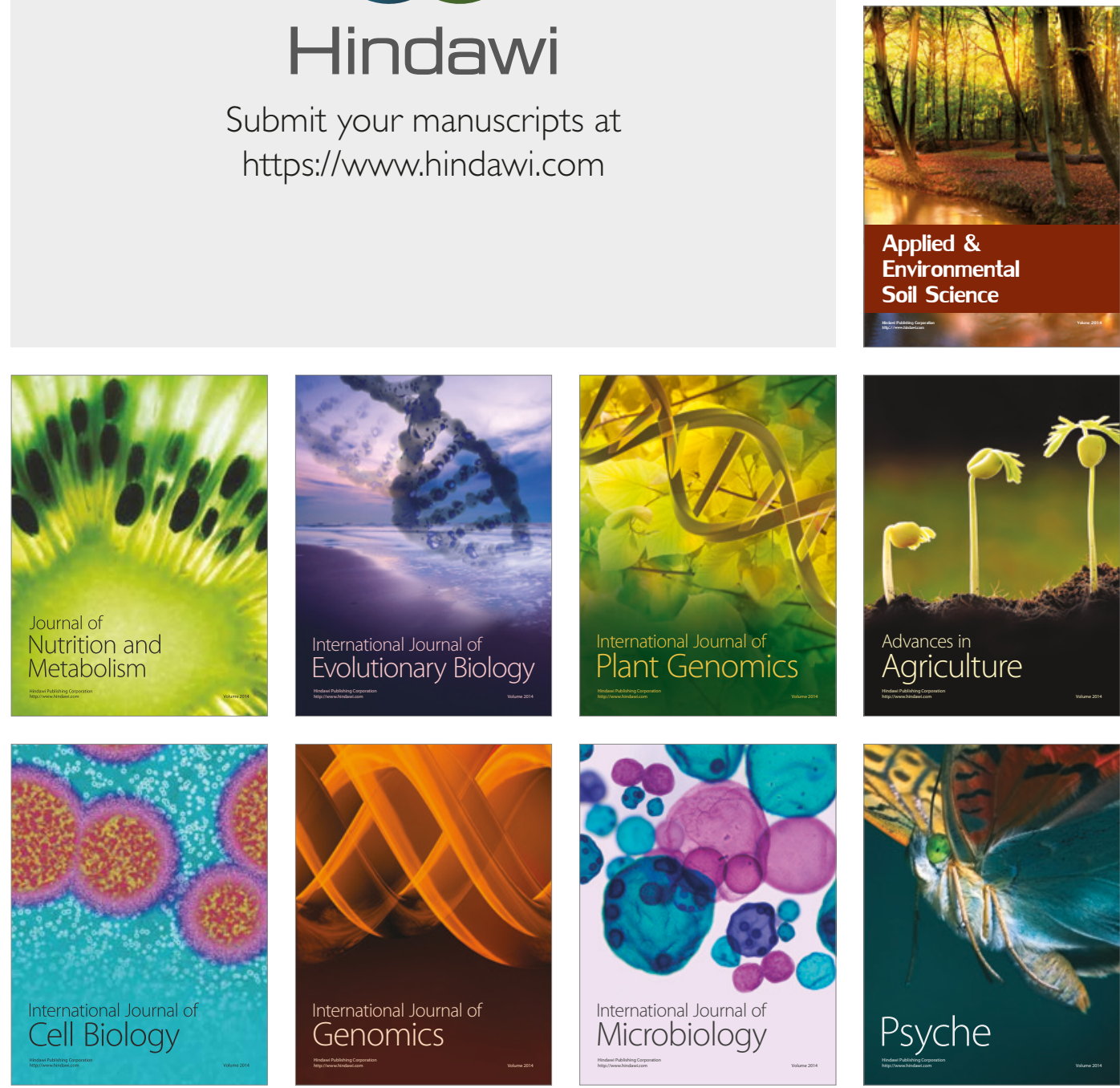

hternational Journal of Microbiology
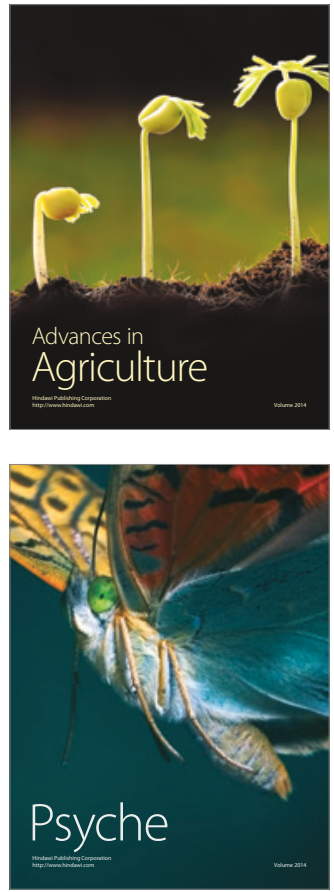